\title{
Acute versus chronic effects of human chorionic gonadotrophin on relaxin secretion in rhesus monkeys
}

\author{
A. C. Ottobre, K. R. Ramsey and J. S. Ottobre \\ Department of Dairy Science, 2027 Coffey Road, The Ohio State University, Columbus, \\ OH 43210, USA
}

\begin{abstract}
Summary. Corpora lutea (CL) were removed from rhesus monkeys $(\mathrm{N}=26)$ at $0 \mathrm{~h}$, 9 h, 3 days, 6 days and 10 days during treatment with hCG to simulate blood concentrations of $\mathrm{CG}$ during normal pregnancy. Dispersed luteal cells were incubated in vitro at $37^{\circ} \mathrm{C}$ for $8 \mathrm{~h}$. Immunoreactive relaxin was measured in incubation medium and in cell extract by radioimmunoassay (RIA). Cellular content and release of relaxin into medium increased as simulated early pregnancy progressed. By 3 days, relaxin content had significantly increased $(P<0.05)$ and continued to rise throughout simulated early pregnancy. Significant increases in cellular content and release were observed before the time when relaxin has been detected in the peripheral circulation during this treatment regimen. Within group, total relaxin (cells plus medium) was similar before and after incubation $(P>0.05)$. As such, production of relaxin during the 8 -h incubation was not evident. In-vitro exposure of the luteal cells to hCG or dbcAMP had no acute effect on cell content or medium concentration of relaxin at any stage of simulated early pregnancy. Since acute effects of hCG and dbcAMP were not evident in vitro, a sustained gonadotrophic influence may be necessary to augment relaxin production/ secretion in the primate CL.
\end{abstract}

Keywords: relaxin; corpus luteum; rhesus monkey; early pregnancy

\section{Introduction}

Peripheral concentrations of immunoreactive relaxin are generally undetectable during the nonfertile menstrual cycle in humans (O'Byrne et al., 1978a; Quagliarello et al., 1979b) and rhesus monkeys (Weiss et al., 1981; Ottobre et al., 1984a), but become measurable during pregnancy (Weiss et al., 1976, 1981; O'Byrne et al., 1978a; Quagliarello et al., 1979a, b). The major source of relaxin in primates is the corpus luteum (CL) (Weiss et al., 1976; Mathieu et al., 1981; Nixon et al., 1983a; Castracane et al., 1983).

Chorionic gonadotrophin (CG) augments relaxin secretion in non-pregnant primates (Quagliarello et al., 1980; Nixon et al., 1983b; Ottobre et al., 1984a), and therefore appears to be a primary stimulus for such enhancement during early pregnancy. When human (h) CG treatments were administered to non-pregnant rhesus monkeys in doses and at times that simulated early pregnancy, immunoreactive relaxin was detected in the serum beginning 6.6 days after the start of CG treatment (Ottobre et al., 1984a). Monitoring serum relaxin values may not be sensitive enough to determine the timing from initial CG exposure to the enhancement of relaxin secretion. A more accurate assessment of this timing would improve our understanding of the regulation of relaxin secretion during early pregnancy.

Investigations of the direct effect of $\mathrm{CG}$ on corpora lutea of the menstrual cycle and pregnancy in vitro have failed to implicate $\mathrm{CG}$ as a potent stimulator of relaxin production or secretion (Goldsmith et al., 1981; Schmidt et al., 1982; Nixon, 1982). Perhaps this should not be surprising 
since CL of the cycle would not have received an endogenous signal for augmentation of relaxin release and $\mathrm{CL}$ of pregnancy were collected after several days of CG influence, a phenomenon known to desensitize CL to the stimulatory effects of hCG on progesterone production (Ottobre $e t$ $a l ., 1989$ ). By using a model for early pregnancy in the primate, it is possible to collect CL at very early and well-defined intervals after endogenous enhancement of relaxin secretion. As such, luteal responses to $\mathrm{CG}$ can be examined before profound desensitization is expressed. This approach provides an alternative assessment of relaxin secretion in the primate that may reveal direct regulatory effects of hCG.

The present study was designed (1) to characterize the pattern of luteal relaxin content and release during simulated early pregnancy, and (2) to examine the acute effects of hCG and dibutyryl (db)cAMP, a second messenger for hCG, on relaxin release by these same luteal cells.

\section{Materials and Methods}

Treatment of animals. The housing and general care of rhesus monkeys at the Ohio State University were as described previously (Johnson et al., 1988). Monkeys were monitored daily for menses (onset of menses = Day 1 of the menstrual cycle). Animals exhibiting regular cycles of approximately 28 days were used. Blood samples were collected daily by femoral venepuncture at 08:00-10:00 h from Day 8 of the menstrual cycle until excision of CL. The serum was stored at $-20^{\circ} \mathrm{C}$ until assayed for hormones. On Day 14 of the cycle, serum concentrations of oestradiol-17 $\beta$ were determined by a rapid RIA (Ottobre et al., 1984b). The day of the LH surge was estimated to occur 1 day before the precipitous decline in oestrogen concentrations that followed the mid-cycle oestrogen peak (Channing, 1980).

Non-pregnant rhesus monkeys received hCG (APL, Wyeth-Ayerst Laboratories, Wheaton, IL, USA) beginning near the expected time of implantation in early pregnancy, i.e. 9-10 days after the mid-cycle LH surge (Ottobre \& Stouffer, 1984). The hCG was injected i.m. twice each day (08:00 and 17:00 h) in doses increasing daily throughout the treatment interval $(15,30,45,90,180,360,720,1440,2880$ and $5760 \mathrm{i} . u$./dose). This regimen resulted in patterns of serum CG similar to those observed in actual early pregnancy (Ottobre \& Stouffer, 1984). CL were removed via midventral laparotomy at various times after the onset of hCG treatment: $0 \mathrm{~h}$ (no hCG treatment; $\mathrm{N}=6$ ), $9 \mathrm{~h}$ $(\mathrm{N}=4), 3$ days $(\mathrm{N}=5), 6$ days $(\mathrm{N}=6)$ and 10 days $(\mathrm{N}=5)$. Monkeys were anaesthetized before surgery with ketamine hydrochloride $(10-15 \mathrm{mg} / \mathrm{kg}$ i.m.) supplemented with atropine sulphate $(0.02 \mathrm{mg} / \mathrm{kg}$ i.m.) and pentobarbitone sodium $(8-12 \mathrm{mg} / \mathrm{kg}$, i.v.). The $\mathrm{CL}$ were excised from the ovary by blunt dissection and immediately placed in Ham's F-10 medium (Sigma, St Louis, MO, USA) at $4^{\circ} \mathrm{C}$ for transport to the laboratory.

Preparation and treatment of tissue. Dispersed luteal cells were prepared by a combination of gentle mechanical agitation and digestion with $0 \cdot 25 \%$ collagenase (Worthington Biochemical, Freehold, NJ, USA) and $0.02 \%$ DNAse (Sigma) (Johnson et al., 1988). Cell viability, as determined by trypan blue exclusion, was $>95 \%$. Suspensions of dispersed luteal cells were incubated in a gyratory shaker bath at a concentration of 50000 luteal cells per $250 \mu \mathrm{l}$ Ham's F-10 medium at $37^{\circ} \mathrm{C}$ in an atmosphere of $95 \% \mathrm{O}_{2}: 5 \% \mathrm{CO}_{2}$. Incubation times of $0 \mathrm{~h}$ (no incubation) and $8 \mathrm{~h}$ were used.

Cells were incubated without treatment, with purified hCG (CR 125; $11900 \mathrm{i} . u$./mg, NIADDK) at concentrations of $0 \cdot 1,1,5,10,50,100,500$ and $1000 \mathrm{ng} / \mathrm{ml}$, or with dibutyryl cAMP (dbcAMP; Sigma) at a concentration of $1 \mathrm{~mm}$ (Ottobre et al., 1989). This concentration of dbcAMP maximally stimulated progesterone production by dispersed luteal cells of the rhesus monkey (Stouffer $e t$ al., 1978). After incubation, cells and medium were separated by centrifugation at $160 \mathrm{~g}$ and then frozen until concentration of relaxin in the medium and content in the cells were estimated by RIA.

Stored relaxin was extracted using mechanical disruption of the cell membranes. Phosphate-buffered saline (PBS) with $1 \%$ ovalbumin was added to previously frozen cells to achieve a concentration of 400000 cells/600 $\mu$ l. The suspension of cells was aspirated 10 times per tube into a $1-\mathrm{ml}$ syringe with a 25 -gauge needle. After aspiration, the extract was centrifuged at $1800 \mathrm{~g}$ for $10 \mathrm{~min}$ to remove cellular fragments. Immediately following centrifugation, $500 \mu \mathrm{l}$ supernatant were removed for direct assay of relaxin. Recovery of exogenous, radioactively labelled relaxin after extraction was $86.8 \pm 1 \cdot 1 \%$ (mean \pm s.e.m., $n=11$ ). To estimate recovery of endogenous relaxin, cells were repeatedly extracted ( 5 times) and extraction buffer was assayed for relaxin after each extraction. Mean recovery of relaxin with single extraction was $56.9 \pm 4.9 \%(n=6)$ of total relaxin recovered. Cellular content of relaxin was corrected by a factor of 0.49 to account for losses due to extraction procedures.

Radioimmunoassay of relaxin. Concentration of relaxin-like immunoreactivity in the incubation medium and content in extracts from dispersed luteal cells were measured by the methods of Sherwood et al. (1975) with modifications. Polytyrosyl-relaxin, generously donated by Dr O. David Sherwood (University of Illinois), was iodinated using chloramine-T (Sherwood et al., 1975). ${ }^{125}$ I-labelled polytyrosyl-relaxin was separated from free ${ }^{125}$ I on a Sephadex G-25 column. Rabbit antiporcine relaxin antiserum (designated R6) (O'Byrne \& Steinetz, 1976; O'Byrne et al., 1978a, b) generously donated by Dr Bernard G. Steinetz (New York University Medical Center) was used (diluted 1:20000 in PBS-EDTA with 1:400 normal rabbit serum). Human relaxin immunoactivity, measured using the R6 
antibody, and bioactivity are similar (O'Byrne $e t$ al., 1978b). In addition, patterns of serum relaxin in pregnant women are similar when assessed with the R6 RIA (O'Byrne et al., 1978a; Quagliarello et al., 1979b) and an homologous human RIA (Bell et al., 1987). Highly purified pig relaxin (Sherwood \& O'Byrne, 1974), donated by Dr $\mathrm{O}$. David Sherwood, was used as a reference standard. The reference standard was diluted in Ham's F-10 medium with $1 \%$ ovalbumin or PBS with $1 \%$ ovalbumin to measure relaxin in medium or cell extract, respectively. Medium sample volumes ranged from 250 to $500 \mu \mathrm{l}$. When relaxin was added to preconditioned medium and assayed over the same range in volume $(250-500 \mu \mathrm{l})$ the slope of the curve was parallel to that of the standard curve. All medium samples were run within one assay and intra-assay variation was $5.43 \%$. The level of detectability (defined as the pg content which corresponds to 2 s.d. from the mean c.p.m. of $\mathrm{B}_{\mathrm{o}}$ replicates) was $199.0 \mathrm{pg}$. Cell extract sample volume was $500 \mu \mathrm{l}$. When relaxin standards $(125-1000 \mathrm{pg})$ were added to cell extract, the curve was parallel to the standard curve. All samples were assayed within the same RIA and intra-assay variation was $6.65 \%$. The level of detectability was $165.8 \mathrm{pg}$. Samples of medium and cell extract with undetectable concentrations of relaxin were assigned a value corresponding to the limit of detectability. Exogenous treatments, hCG and dbcAMP, did not interfere with the assay.

Statistical analyses. Medium concentrations and cell content of relaxin were compared among groups using analyses of variance. For each analysis that demonstrated significance $(P<0.05)$ by an $\mathrm{F}$ test, comparisons were made between pairs of groups using the least significant difference method. Pre-incubation and post-incubation levels of relaxin were compared within groups by using paired $t$ tests. Data were transformed to natural logarithms when there was heterogeneity of variance among groups. To evaluate overall production during incubation for $8 \mathrm{~h}$, the total amount of relaxin stored and released by 400000 cells was determined by adding the content of relaxin in 400000 cells with the amount of relaxin in the corresponding $2 \mathrm{ml}$ incubation medium. Comparisons of total relaxin (cell content plus medium content) between groups were made as stated above for medium concentrations and cell contents. Total relaxin was not evaluated in the $0 \mathrm{~h}$ group due to insufficient data.

Response to hCG in vitro was examined within groups using analyses of variance for a randomized completeblock design with individual CL as the block. Response to a single dose of dbcAMP (I mM) was examined within each group using $t$ tests. The relationship between concentrations of relaxin in medium after incubation and basal production of prostaglandins by these same cells (Ottobre et al., 1989) was estimated by calculation of the correlation coefficient.

\section{Results}

The content of relaxin in cells before incubation was detectable in $5 / 6$ untreated monkeys $(0 \mathrm{~h})$, but was above the limit of assay sensitivity in only $1 / 4$ monkeys at $9 \mathrm{~h}$ after the initial hCG treatment. By Day 3 of simulated early pregnancy, cellular content of relaxin had significantly increased $(P<0.05)$ and continued to rise (Fig. 1a). Cell content of relaxin declined in all groups during incubation of cells for $8 \mathrm{~h}(P<0.05$, except at $9 \mathrm{~h}$ when $P=0.21)$. Treatment with hCG in vitro had no acute effect on cellular content of relaxin at any dose tested or at any stage of simulated early pregnancy. Similarly, incubation with $1 \mathrm{mM}$-dbcAMP did not change the content of relaxin in cells compared to untreated cells. Data for cellular content of relaxin after incubation for $8 \mathrm{~h}$ in the absence of treatment and in the presence of the highest dose of hCG or $1 \mathrm{mM}$-dbcAMP are shown in Table 1.

Concentrations of relaxin in incubation medium before and after incubation increased as simulated early pregnancy progressed $(P \leq 0.01$; Fig. 1b). Relaxin concentrations in medium from the 0 -h group were all below the level of detectability of the assay. In the 9 -h group, concentrations of relaxin in the medium after incubation were near or above the level detectable by the assay. After 3 days of hCG treatment in vivo, relaxin was detectable in medium incubated with cells from all but one animal. Increases in relaxin concentration were clearly evident at 6 and 10 days of simulated early pregnancy. The concentrations of relaxin in the medium increased $(P<0.05)$ during incubation in the 3-, 6- and 10-day groups $(0 \mathrm{~h}$ could not be analysed due to insufficient numbers of samples representing both pre- and post-incubation). This reflects an increase in relaxin secreted into the medium as simulated early pregnancy progressed. This increased secretion was directly related to absolute levels of relaxin, since the percentage of total relaxin that was secreted did not change (Table $2 ; P>0 \cdot 1$ ). In-vitro treatment of cells with hCG or dbcAMP did not affect the amount of relaxin secreted into the medium during the incubation period (Table 1).

To evaluate production of relaxin by luteal cells during incubation, the amount of relaxin stored in 400000 cells and the amount of relaxin released into the corresponding medium $(2 \mathrm{ml})$ were 


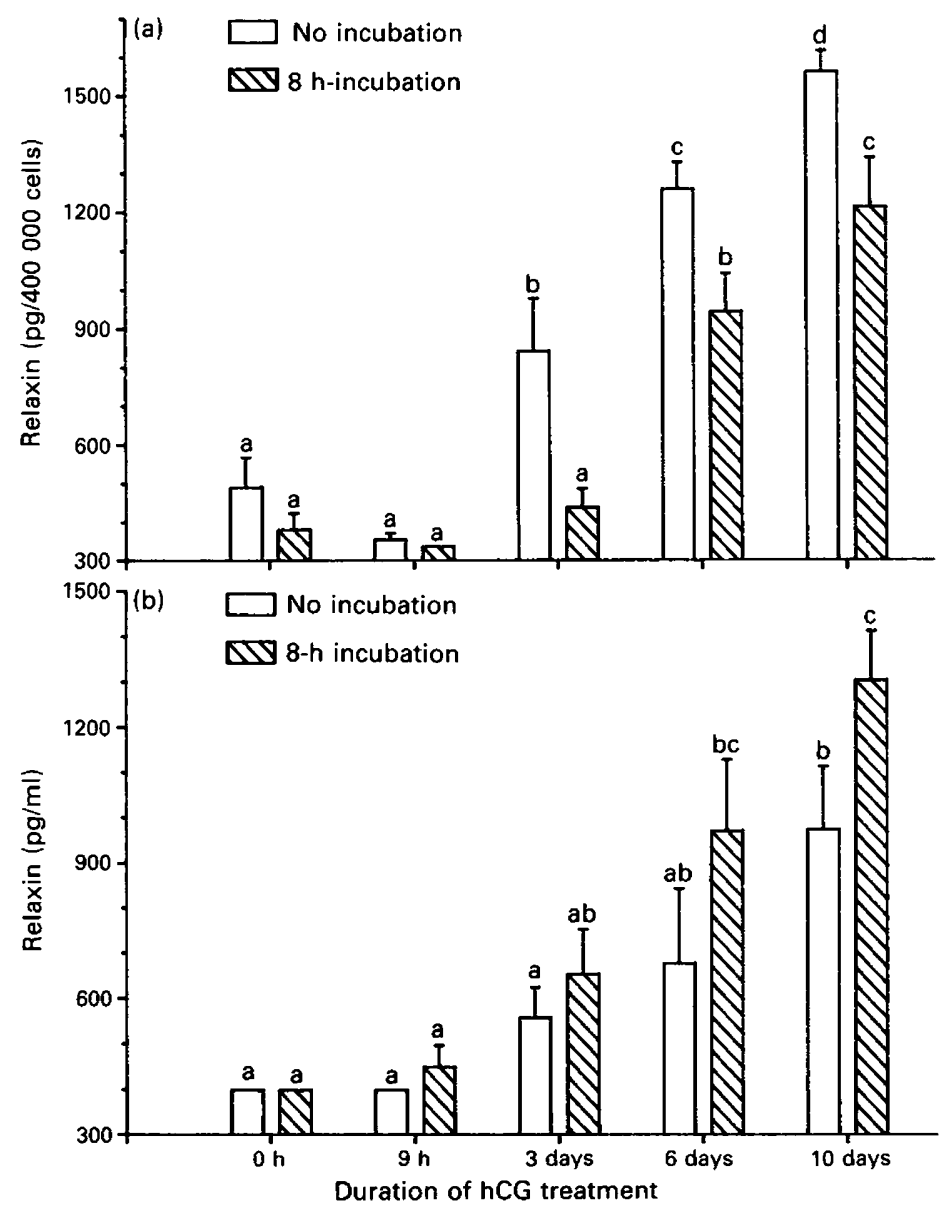

Fig. 1. The content of relaxin in dispersed luteal cells (a) and the concentrations of relaxin in medium incubated with dispersed luteal cells (b). CL were excised from monkeys at various times after the start of treatment with hCG. Dispersed luteal cells were incubated at $37^{\circ} \mathrm{C}$ for $8 \mathrm{~h}$ at a concentration of 50000 cells $/ 250 \mu \mathrm{l} /$ tube. Each bar represents the mean \pm s.e.m. for (a) 3-4 CL group and (b) 4-5 CL/group except $0 \mathrm{~h}, 8$-h incubation $(n=2)$ and $9 \mathrm{~h}$, no incubation $(n=3)$. Relaxin values were corrected for extraction losses. Comparisons of relaxin values were made among times of simulated early pregnancy within incubation time. Means with different letter designations were significantly different $(P<0.05)$. Sensitivity of the RIA, adjusted by the same factor used to correct the samples for extraction losses, was (a) $335.6 \mathrm{pg} /$ 400000 cells, and (b) $398 \cdot 0 \mathrm{pg} / \mathrm{ml}$.

totalled at $0 \mathrm{~h}$ and at $8 \mathrm{~h}$. The patterns of total relaxin before and after incubation for $8 \mathrm{~h}$ were similar to those for cell content or medium concentration alone. Relaxin tended to increase by 3 days of simulated early pregnancy and continued to increase as simulated early pregnancy progressed $(P<0.01$, pre-incubation; $P<0.01$, post-incubation; Fig. 2$)$. Within group, total relaxin was similar before and after incubation $(P>0.05)$. Production of relaxin during the 8 -h incubation was therefore not evident.

We have previously reported the production of prostaglandins by these same luteal cells (Ottobre et al., 1989). The correlations between concentrations of relaxin in medium after incubation and basal production of PGE- 2 and PGF- $2 \alpha$ during the same time period were +0.78 
Table 1. Relaxin content in cells and concentration in medium after incubation $(8 \mathrm{~h})$ of luteal cells in the presence and absence of human chorionic gonadotrophin (hCG) or dibutyryl (db)cAMP

\begin{tabular}{lccc}
\hline & \multicolumn{4}{c}{ Day of simulated early pregnancy } \\
\cline { 2 - 4 } Treatment & 3 & 6 & 10 \\
\hline \multicolumn{4}{c}{ Cell content $($ ng/400 } \\
None & $0.44 \pm 0.05$ & $0.94 \pm 0.10$ & $1.21 \pm 0.13$ \\
hCG $(1000 \mathrm{ng} / \mathrm{ml})^{*}$ & $0.48 \pm 0.14$ & $1.02 \pm 0.08$ & $0.98 \pm 0.06$ \\
dbcAMP $(1 \mathrm{mM})$ & $0.44 \pm 0.04$ & $1.04 \pm 0.08$ & $1.10 \pm 0.12$ \\
& \multicolumn{4}{c}{ Concentration in medium $(\mathrm{ng} / \mathrm{ml})$} \\
None & $0.65 \pm 0.10$ & $0.97 \pm 0.16$ & $1.31 \pm 0.11$ \\
hCG $(1000 \mathrm{ng} / \mathrm{ml})^{*}$ & $0.52 \pm 0.12$ & $0.94 \pm 0.10$ & $1.53 \pm 0.20$ \\
dbcAMP $(1 \mathrm{mM})$ & $0.56 \pm 0.09$ & $0.97 \pm 0.18$ & $1.45 \pm 0.07$ \\
\hline
\end{tabular}

Values are mean \pm s.e.m.

$n$ for cell content $=3-4 \mathrm{CL} /$ group except hCG Day $3(n=2)$ and hCG Day $10(n=2)$. For conservative analysis, data include cell content when extractions were done on 400000 cells. When data are included from extractions of $\leqslant 400000$ cells ( $n=5-6 \mathrm{CL} /$ group), similar responses to hCG were observed.

$n$ for concentration in medium $=4-6 \mathrm{CL} /$ group except cAMP Day 10 $(n=3)$.

Relaxin concentrations did not differ among treatments within day $(P>0 \cdot 1)$.

*The responses to the highest dose of hCG are represented in this table. All doses of hCG tested yielded similar responses.

Table 2. Percentage of total relaxin (cells plus medium) that was secreted into the medium during incubation for $8 \mathrm{~h}$

\begin{tabular}{cc}
\hline $\begin{array}{c}\text { Duration of } \\
\text { hCG treatment }\end{array}$ & $\begin{array}{c}\% \text { of total relaxin } \\
\text { secreted into the medium }\end{array}$ \\
\hline $9 \mathrm{~h}$ & $72 \cdot 3 \pm 1 \cdot 9^{*}$ \\
3 days & $72 \cdot 8 \pm 3 \cdot 9$ \\
6 days & $64 \cdot 7 \pm 3 \cdot 2$ \\
10 days & $68 \cdot 3 \pm 2 \cdot 8$ \\
\hline Values are mean \pm s.e.m. of [medium]/[cells + \\
medium] $\times 100 \%$ ( $n=4$ corpora lutea/group). \\
Groups did not differ significantly $(P>0 \cdot 1)$.
\end{tabular}

$(P<0.01)$ and $+0.67(P<0.01)$, respectively. There was not a significant correlation with 6-keto-PGF-1 $\alpha$ production $(\mathrm{R}=-0.08, P>0.05)$.

\section{Discussion}

Administration of hCG to rhesus monkeys in a manner that invokes pregnancy-like patterns of circulating $\mathrm{CG}$ during the luteal phase of the non-fertile menstrual cycle induced a progressive increase in concentrations of immunoreactive relaxin associated with luteal cells. Based on data from non-pregnant primates (O'Byrne et al., 1978a; Quagliarello et al., 1979b; Weiss et al., 1981; Ottobre et al., 1984a; Stewart et al., 1990) and due to the limited lifespan of CL of the non-fertile 


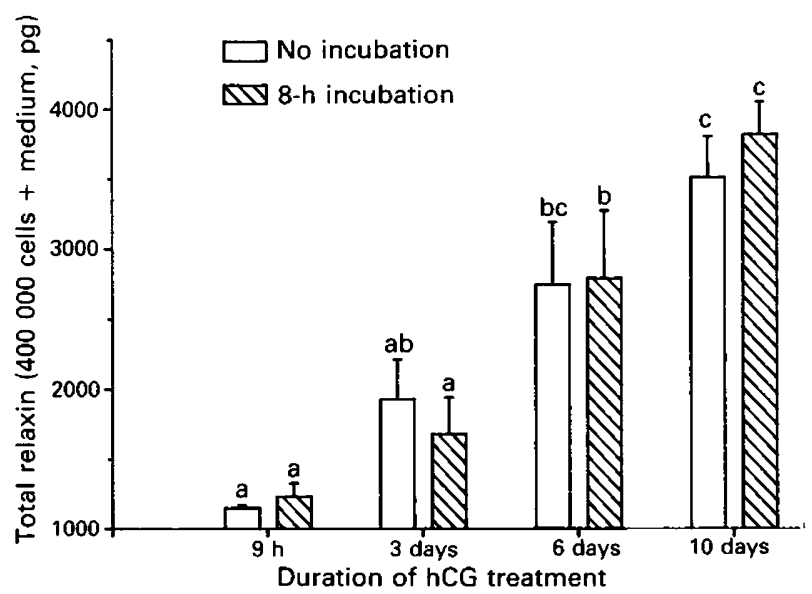

Fig. 2. Total relaxin, stored and released, by 400000 dispersed luteal cells from corpora lutea collected at various times during simulated early pregnancy. Sensitivity in terms of total relaxin was the sum of sensitivity for cell content ( $\mathrm{pg} / 400000$ cells) plus sensitivity for medium concentration $(\mathrm{pg} / 2 \mathrm{ml})$. Values are mean \pm s.e.m. for 3-4 CL/group. Means with different letter designations are significantly different $(P<0.05)$.

cycle, a progressive rise of a similar nature does not occur in untreated non-pregnant primates. Patterns of relaxin concentrations in incubation medium from luteal cells of the current study (before and after incubation), as well as patterns of cell content, were consistent with patterns of serum relaxin which are induced during simulated early pregnancy in the monkey (Ottobre et al., 1984a). Although relaxin was not detected in the peripheral circulation until 6.6 days after the start of hCG treatment (Ottobre et al., 1984a), the first significant accumulation of relaxin in luteal cells occurred by 3 days of simulated early pregnancy. Luteal relaxin continued to increase throughout simulated early pregnancy. These results indicate that stimulation of relaxin synthesis by luteal cells of the rhesus monkey occurs within 3 days of the initiation of hCG treatment. Based on patterns of peripheral relaxin in other primates treated with CG (Quagliarello et al., 1980; Castracane et al., 1983), the timing of the augmentation of relaxin secretion in vivo by exogenous CG treatment appears to be similar among rhesus monkeys, women and baboons. The delay between the initial treatment with CG and the subsequent response in terms of relaxin release may indicate that a sustained gonadotrophic influence is necessary to enhance luteal relaxin production/secretion. An acute effect of gonadotrophin stimulation in vivo is as yet equivocal. In the current study, 5 of $6 \mathrm{CL}$ harvested before treatment $(0 \mathrm{~h})$ contained detectable concentrations of relaxin; however, only 1 of $4 \mathrm{CL}$ harvested $9 \mathrm{~h}$ after in-vivo treatment with hCG contained detectable relaxin. Perhaps hCG caused an acute release of low level relaxin stores in vivo.

The lack of a definitive acute effect of hCG on relaxin production/secretion in vivo is supported by the lack of such an effect of hCG or cAMP in vitro. This is despite the fact that CL were tested after in-vivo augmentation of relaxin secretion, and before complete desensitization to hCGstimulated progesterone production. Nevertheless, although these luteal cells did not respond to hCG and dbcAMP in terms of relaxin production, they did respond steroidogenically to these agents (Ottobre et al., 1989). Although there was a gradual desensitization to hCG-stimulated production of progesterone, hCG continued to enhance progesterone synthesis in vitro throughout Day 6 of simulated early pregnancy in these same luteal cells. Furthermore, dbcAMP stimulated progesterone production throughout the entire 10 days of simulated early pregnancy. In terms of oestradiol production, the response of these same luteal cells to hCG and dbcAMP was actually enhanced as simulated early pregnancy progressed through Day 6. Data such as these raise questions relative to a direct obligatory role of hCG in the regulation of relaxin secretion. Perhaps 
hCG, by providing an extension of the luteal phase, permits augmentation of relaxin secretion to develop constitutively or to develop in response to other stimuli.

In the present study, the release of relaxin in vitro was dependent on the stage of simulated early pregnancy, and was related to cellular content of relaxin. The amount of relaxin released from luteal cells during the 8-h incubation increased as simulated early pregnancy advanced; however, the percentage of total relaxin secreted into the medium remained the same. This indicates that, although the propensity to release relaxin increased throughout simulated early pregnancy, the amount of relaxin released reflected the amount present in the cells. Furthermore, total relaxin (concentration in cells + medium) did not change before and after incubation and, as such, production of relaxin during the 8-h incubation was not evident.

The concentrations of relaxin in medium after incubation of luteal cells were positively correlated with basal luteal production of PGE-2 and PGF-2 $\alpha$ by the same cells throughout simulated early pregnancy. Such a relationship is consistent with the possibility that prostaglandins play a role in the regulation of relaxin production/secretion. This notion is further supported by reports of in-vitro and/or in-vivo stimulation of relaxin release from pig CL by PGE-2 (Taylor \& Clarke, 1987) and PGF-2 $\alpha$ (Sherwood et al., 1979; Nara et al., 1982; Taylor \& Clarke, 1987; Taylor et al., 1987). Further studies are necessary to confirm an involvement of prostaglandins of luteal origin in the local regulation of relaxin secretion.

Finally, relaxin has generally been considered to be a pregnancy related hormone in primates (O'Byrne et al., 1978a; Quagliarello et al., 1979a, b) and is generally not detectable in the peripheral circulation in the absence of pregnancy. However, there is evidence that relaxin may be present during the menstrual cycle. Relaxin immunoreactivity is found in non-pregnant primates in peritoneal fluid (Thomas et al., 1982; Loumaye et al., 1984), luteal cysts (Loumaye et al., 1978), luteal extracts (O'Byrne et al., 1978b) and ovarian venous plasma draining the CL-bearing ovary (Khan-Dawood et al., 1989). Recently, using a very sensitive enzyme-immunoassay for human relaxin, peripheral relaxin was detected during the luteal phase of non-pregnant women (Stewart $e t$ al., 1990). In addition, the CL of non-pregnant women has been shown to express the relaxin gene (Ivell et al., 1989). In the current study, low levels of relaxin were detectable in cells harvested from mid-luteal phase CL. Relaxin secretion is therefore augmented during early pregnancy rather than induced per se.

We thank Dr A. R. Dalessandro and B. S. Houmard for technical and scientific contributions; Dr O. D. Sherwood and Dr B. G. Steinetz for assistance in development of the relaxin radioimmunoassay and donations of assay reagents; Dr D. R. Deaver for generous donations of second antibody; Wyeth-Ayerst Laboratories for hCG (APL); the Pituitary Hormone Distribution Program, NIADDK, for purified hCG; and Michelle Milligan for help in preparing the manuscript. This work was supported by NIH Grant HD-21319. Salaries and additional research support were provided by State and Federal funds appropriated to the Ohio Agricultural Research and Development Center, The Ohio State University. Journal Article No. 22-90.

\section{References}

Bell, R.J., Eddie, L.W., Lester, A.R., Wood, E.C., Johnston, P.D. \& Niall, H.D. (1987) Relaxin in human pregnancy serum measured with an homologous radioimmunoassay. Obstet. Gynecol. 69, 585-589.

Castracane, V.D., D'Eletto, R. \& Weiss, G. (1983) Relaxin secretion in the baboon (Papio cynocephalus). In Factors Regulating Ovarian Function, pp. 415-419. Eds G. S. Greenwald \& P. G. Terranova. Raven Press, New York.
Channing, C.P. (1980) Progesterone and estrogen secretion by cultured monkey ovarian cell types: influences of follicular size, serum luteinizing hormone levels, and follicular fluid estrogen levels. Endocrinology 107, 342-353.

Goldsmith, L.T., Essig, M., Sarosi, P., Beck, P. \& Weiss, G. (1981) Hormone secretion by monolayer cultures of human luteal cells. J. clin. Endocr. Metab. 53, 890-892.

Ivell, R., Hunt, N., Khan-Dawood, F. \& Dawood, Y. 
(1989) Expression of the human relaxin gene in the corpus luteum of the menstrual cycle and in the prostate. Molec. cell. Endocr. 66, 251-255.

Johnson, M.S., Ottobre, A.C. \& Ottobre, J.S. (1988) Prostaglandin production by corpora lutea of rhesus monkeys: characterization of incubation conditions and examination of putative regulators. Biol. Reprod. 39, 839-846.

Khan-Dawood, F.S., Goldsmith, L.T., Weiss, G. \& Dawood, M.Y. (1989) Human corpus luteum secretion of relaxin, oxytocin, and progesterone. $J$. clin. Endocr. Metab. 68, 627-631.

Loumaye, E., Teuwissen, B. \& Thomas, K. (1978) Characterization of relaxin radioimmunoassay using BoltonHunter reagent. Gynecol. Obstet. Invest. 9, 262-267.

Loumaye, E., Depreester, S., Donnez, J. \& Thomas, K. (1984) Immunoreactive relaxin surge in the peritoneal fluid of women during the midluteal phase. Fert. Steril. 42, 856-860.

Mathieu, P., Rahier, J. \& Thomas, K. (1981) Localization of relaxin in human gestational corpus luteum. Cell Tissue Res. 219, 213-216.

Nara, B.S., Ball, G.D., Rutherford, J.E., Sherwood, O.D. \& First, N.L. (1982) Release of relaxin by a nonluteolytic dose of prostaglandin F-2 $\alpha$ in pregnant swine. Biol. Reprod. 27, 1190-1195.

Nixon, W.E. (1982) In vitro relaxin and progesterone secretion by nonhuman primate (Macaca mulatta) luteal cells. Endocrinology 110, (Suppl.), 274, Abstr. 778.

Nixon, W.E., Reid, R., Abou-Hozaifa, B.M., Williams, R.F., Steinetz, B.G. \& Hodgen, G.D. (1983a) Origin and regulation of relaxin secretion in monkeys: effects of chorionic gonadotropin, luteectomy, fetectomy, and placentectomy. In Factors Regulating Ovarian Function, pp. 427-431. Eds G. S. Greenwald \& P. F. Terranova. Raven Press, New York.

Nixon, W.E., Schenken, R.S. \& Reid, R. (1983b) Relaxin response to ovarian hyperstimulation during the menstrual cycle in monkeys. Endocrinology 112 (Suppl.), 387, Abstr. 1227.

O'Byrne, E.M. \& Steinetz, B.G. (1976) Radioimmunoassay (RIA) of relaxin in sera of various species using an antiserum to porcine relaxin (39377). Proc. Soc. exp. Biol. Med. 152, 272-276.

O'Byrne, E.M., Carriere, B.T., Sorensen, L., Segaloff, A., Schwabe, C. \& Steinetz, B.G. (1978a) Plasma immunoreactive relaxin levels in pregnant and nonpregnant women. J. clin. Endocr. Metab. 47, 1106-1110.

O'Byrne, E.M., Fliteraft, J.F., Sawyer, W.K., Hochman, J., Weiss, G. \& Steinetz, B.G. (1978b) Relaxin bioactivity and immunoreactivity in human corpora lutea. Endocrinology 102, 1641-1644.

Ottobre, J.S. \& Stouffer, R.L. (1984) Persistent versus transient stimulation of the macaque corpus luteum during prolonged exposure to human chorionic gonadotropin: a function of age of the corpus luteum. Endocrinology 114, 2175-2182.

Ottobre, J.S., Nixon, W.E. \& Stouffer, R.L. (1984a) Induction of relaxin secretion in rhesus monkeys by human chorionic gonadotropin: dependence on the age of the corpus luteum of the menstrual cycle. Biol. Reprod. 31, 1000-1006.

Ottobre, J.S., Ottobre, A.C. \& Stouffer, R.L. (1984b) Changes in available gonadotropin receptors in the corpus luteum of the rhesus monkey during simulated early pregnancy. Endocrinology 115, 198-204.

Ottobre, J.S., Houmard, B.S. \& Ottobre, A.C. (1989) Luteal production of steroids and prostaglandins during simulated early pregnancy in the primate: differential regulation of steroid production by chorionic gonadotropin. Biol. Reprod. 41, 393-400.

Quagliarello, J., Steinetz, B.G. \& Weiss, G. (1979a) Relaxin secretion in early pregnancy. Obstet. Gynecol. 53, 62-63.

Quagliarello, J., Szlachter, N., Steinetz, B.G., Goldsmith, L.T. \& Weiss, G. (1979b) Serial relaxin concentrations in human pregnancy, Am. J. Obstet. Gynecol. 135, 43-44.

Quagliarello, J., Goldsmith, L., Steinetz, B., Lustig, D.S. \& Weiss, G. (1980) Induction of relaxin secretion in nonpregnant women by human chorionic gonadotropin. J. clin. Endocr. Metab. 51, 74-77.

Schmidt, C.L., Black, V.H. \& Weiss, G. (1982) Hormonal and ultrastructural studies of long-term monolayer cultures of human luteal cells. Endocrinology 110 (Suppl.), 269, Abstr. No. 758.

Sherwood, O.D. \& O'Byrne, E.M. (1974) Purification and characterization of porcine relaxin. Archs Biochem. Biophys. 160, 185-196.

Sherwood, O.D., Rosentreter, K.R. \& Birkhimer, M.L. (1975) Development of a radioimmunoassay for porcine relaxin using ${ }^{125}$ I-labeled polytyrosyl-relaxin. Endocrinology 96, 1106-1113.

Sherwood, O.D., Nara, B.S., Crnekovic, V.E. \& First, N.L. (1979) Relaxin concentrations in pig plasma after the administration of indomethacin and prostaglandin F-2 $\alpha$ during late pregnancy. Endocrinology 104, $1716-1721$.

Stewart, D.R., Celniker, A.C., Taylor, C.A., Jr, Cragun, J.R., Overstreet, J.W. \& Lasley, B.L. (1990) Relaxin in the peri-implantation period. J. clin. Endocr. Metab. 70, 1771-1773.

Stouffer, R.L., Nixon, W.E. \& Hodgen, G.D. (1978) The refractory state of luteal cells isolated from rhesus monkeys after prolonged exposure to chorionic gonadotropin during early pregnancy. Biol. Reprod. $18,858-864$.

Taylor, M.J. \& Clark, C.L. (1987) Detection of relaxin release by porcine luteal cells using a reverse hemolytic plaque assay: effect of prostaglandins E-2 and $\mathrm{F}-2 \alpha$, human chorionic gonadotropin, and oxytocin. Biol. Reprod. 37, 377-384.

Taylor, M.J., Clark, C.L. \& Frawley, L.S. (1987) Analysis of relaxin release from cultured porcine luteal cells by reverse hemolytic plaque assay: Influence of gestational age and prostaglandin F-2 $\alpha$. Endocrinology 120, 2085-2091.

Thomas, K., Loumaye, E. \& Donnez, J. (1982) Immunoactive relaxin in the peritoneal fluid during spontaneous menstrual cycle in women. Ann. N.Y. Acad. Sci. 380, 126-130.

Weiss, G., O'Byrne, E.M. \& Steinetz, B.G. (1976) Relaxin: a product of the human corpus luteum of pregnancy. Science, NY 194, 948-949.

Weiss, G., Steinetz, B.G., Dierschke, D.J. \& Fritz, G. (1981) Relaxin secretion in the rhesus monkey. Biol. Reprod. 24, 565-567.

Received 29 May 1990 